\title{
A Simulation Supply Chain Model for a Sustainable and Environment Friendly Poultry Industry: Insights from Bangladesh
}

\author{
Mohammad Shamsuddoha \\ Graduate Research Student \\ Graduate School of Business, Curtin University \\ E-mail: $\underline{\text { mdsdoha@gmail.com }}$
}

Desmond Klass

Associate Professor of Graduate School of Business

Curtin University

E-mail: Des.Klass@gsb.curtin.edu.au

Mohammed Quaddus

Professor of Graduate School of Business

Curtin University

E-mail: Mohammed.Quaddus@gsb.curtin.edu.au 


\title{
A Simulation Supply Chain Model for a Sustainable and Environment Friendly Poultry Industry: Insights from Bangladesh
}

\begin{abstract}
The focus on environment and reverse supply chain has increased in recent years among academic and industry circles. Bangladesh poultry is to yet achieve environmental sustainability in her extended forward and reverse supply chain. In this paper, a supply chain model was developed based on a case poultry industry. Design science, case method and positivist paradigm were adopted to develop a simulation model using simul8 application to fit real poultry operation. The several objectives of this paper include a review of the literature, development of a simulation supply chain model and testing of it using historic data. The paper discusses the results of the model developed to capture the relationship among the forward, reverse and mainstream supply chains. Different random trials were conducted using simulation package that clearly demonstrated the usefulness of the model in determining optimal scenarios.
\end{abstract}

Keywords: Sustainability, Environment, Reverse Supply Chain, Poultry Industry, Bangladesh

\section{INTRODUCTION}

Poultry sub-sector in Bangladesh is contributing in a prolific way to the economy and has a good reputation for providing self-employment opportunities, cheap sources of protein supply, and income sources for millions of people. Though this industry has contributed to the economy, it has failed to adapt modern technology for poultry procurement and processing along with sustainability, supply chain, and environmental issues. Sustainability, reverse supply chain, and environment (Corbett and Kleindorfer 2003) are proving to be highly important due to its direct influence in achieving competitiveness in the 
local and global market. Major industries are under tremendous pressure by stakeholders to practice environment friendly operations. Stakeholders are desperate to see that companies are spending money and adopting strategies and methods to preserve the environment. In these circumstances, it is vital to combine environment, sustainability and reverse supply chain concepts in their production and procurement process. Bangladesh poultry is trading millions of dollars but does not have structured supply chain processes with the vision of encompassing environment friendly concepts. As a result, this industry is damaging the environment, which needs to be ideal for an over populated country like Bangladesh. Bangladesh poultry needs structured and scientific supply chain model that must be inclusion of sustainability, efficient forward and reverse supply chain process, environmental issues, profitability, and optimality concepts. This research focuses on a case industry to see how supply chain and environment practices can be utilised to protect the environment for the next generation in a profitable way.

\section{RESEARCH JUSTIFICATION}

In Bangladesh, environmental issues are increasingly important due to huge population pressures, limited land resources, food crises and drastic climate changes (Shamsuddoha, 2011). They are struggling to operate their livestock businesses with zero environmental hazards. Strong awareness is mounting in support of implementing reverse supply chain concept at the industry and society level. Nevertheless, significant percentage of poultry farmers do not have scientific knowledge on poultry waste management which results in tons of poultry wastages being dumped in the lowlands, rivers and vacant lands. A noteworthy research gap exists in the implementation of proper supply chain theory to this particular industry and its operations. This research proposes a poultry model, which includes the concept of reverse supply chains. The use of reverse supply chains has the potential of removing environmental hazards by utilizing existing poultry wastages. Various by-products can be made from poultry wastages for home and 
industry use that is socially, economically, and environmentally viable for the Bangladesh context. This approach has the potential for creating new small and medium enterprises (SMEs) that will contribute towards more employment opportunities. In this research, the environment gets priority and the focus is for the industry to reuse their wastage to create valuable further output. It is important to conduct research on this burning issue as millions of people directly and indirectly involved with this industry for their source of income. Here, the researchers develops a simulation supply chain model, which will provide a better understanding of poultry waste management for the sake of protecting the environment. This simulation model can be examined virtually to gain insights and a good understanding of the implications and the benefits of various strategies rather than experimenting and consuming resources within the real life situation.

\section{LITERATURE}

Supply chain is the process that starts from the initial raw materials to the ultimate consumption of the finished product linking across suppliers, user companies; and within and outside a company (Cox et al., 1995). Supply chains link the internal and external partners of suppliers, carriers, third-party companies, and information systems providers. A key point in supply chain management is that the entire process must be viewed as one system (Lummus and Vokurka, 1999). Supply chain concepts provide a step towards the broader adoption and development of sustainability that integrates issues of disposal, recycling, reconditioning, and remanufacturing of used products (Kocabasoglu et al., 2007). Supply chains also include the consideration of product design, manufacturing by-products, by-products produced during product use, product life extension, product end-of-life, and recovery processes at endof-life (Jonathan et al., 2007). 
Sustainability is also glimpse as "the potential for reducing long-term risks associated with resource depletion, fluctuations in energy costs, pollution, and waste management" (Shrivastava, 1995a). Within the management literature, organizational sustainability focused on ecological durability with only implicit recognition of social and economic responsibilities (Jennings, 1995). The '3R' concept is also well accepted and focuses on practices that aim to reduce, reuse, and recycle, particularly in the context of production and consumption. These ideas apply to the entire lifecycle of products and services from design and extraction of raw materials, to transport, manufacture, use, dismantle, and reuse, and disposal (Srinivas, 2007). The supply chain planning using reverse logistics of end-of-life (EOL) products embraces many different characteristics of environmentally conscious manufacturing, including disassembly, reuse, recycling, and remanufacturing (Gungor and Gupta, 1999).

Managers are facing tremendous pressure to adopt sustainable supply chains that address increasing environmental concerns (Klassen and Vachon, 2003). Environmental issues are increasingly considering a priority alongside other business matters due to scarcity of resources and rapid climate change. One of the dynamic concept of reverse supply chain (RSC), which is related to the concept of recycle, reuse and reduce may be applied to waste management. RSC refers to the series of activities necessary to retrieve a used product (or a product waste) from a customer and either dispose of it or recover value from it (Prahinski and Kocabasoglu, 2006, Guide and Van, 2002). RSC has the potential of reducing negative environmental impacts by extracting virgin raw material and waste disposal (Kocabasoglu et al., 2007). Until now, poultry literature was limited to identifying and assessing environmental impact of on-farm gaseous and nutrient discharge (Pelletier 2008). Food and Agriculture Organization (FAO) identified that livestock sector is top two or three contributors for environmental problems of water and air pollution, land degradation, and biodiversity loss (Steinfeld et al. 2006). Even with this evidence, the environmental issues of poultry production from a supply chain perspective have received little attention. This paper takes account of this research gap as it relates to poultry, the supply chain and the environment. 


\section{METHODS}

This study covers a literature review on environmental sustainability, reverse supply chain, and the Bangladesh poultry industry. The study adopted positivist ontology, empirical epistemology, and a quantitative methodology based on a case study of a real poultry case. The design science methodology and case study method was chosen for this study. Design science is concerned with "devising artifacts to attain goals (Simon, 1969) and is based on "build and evaluate" an artifact of a model (March \& Smith, 1995). An artifact means designing and developing soft or hard objects that can meet specific purposes and goals (Venable, 2006a, 2006b). A Case study on the other hand involves observing the descriptions of particular instances of an occurrence (Yin 1994). Both primary and secondary information was used in this study. Primary information collected from April 2011 to May 2011, mainly through in-depth interviews with respondents over the telephone. This paper used in-depth interviews and observation tools to gain insights into supply chain processes to understand and develop a sustainable environment friendly simulation model on poultry. The case used in this study involves one of the biggest and reputed farms in Bangladesh. They produce around 150,000 day old chicks per week and have nearly 200 employees. The total respondents interviewed included the five top executives from the case organisation. The respondents nominated for open-ended questions relating to understands required process based on their widespread knowledge and experiences. The in-depth interview lasted about an hour for each respondents and information relating to production, process and waste management were discussed. Secondary information was also collected from different published documents such as referral books, journals, and conference papers, statistical yearbooks and company record and reports. In addition, existing industry databases were used to get different distribution pattern for various simulation artifacts. The simulation package SIMUL8 (version 17) was used to develop the poultry model and trivial analyses of existing poultry processes was conducted in order to investigate the research objectives. 


\section{POULTRY INDUSTRY IN BANGLADESH IN LIGHT OF ENVIRONMENT}

As an important sub-sector of livestock production, the poultry industry in Bangladesh plays a crucial role in economic growth and simultaneously creates numerous employment opportunities (Shamsuddoha and Sohel, 2008). Poultry plays a key role in the country's economy through its direct and indirect involvement for about $73 \%$ of people living in rural areas. Bangladesh has a long history of poultry rearing under traditional backyard farming practices (Reneta, 2005). Poultry is dominated by backyard local chickens (Desi or local), which mostly survive through a natural scavenger system (Nielsen, 2007). Poultry is one of the alternative incomes generating activity for the poor in Bangladesh (Shamsuddoha and Sohel, 2004). The poultry industry, a fundamental part of animal production, is committed to supplying the nation with a cheap source of good quality nutritious animal protein in terms of meat and eggs (Shamsuddoha, 2010) and as such can contribute massively to the GDP if the industry is able to utilize all the internal resources. In the early nineties, a number of private parent stock and breeder farms shifted their operations to produce commercial day-old broiler and layer chicks (Reneta Statistical Year Book, 2005). Poultry farms have grown up mostly through private ownership that possesses inadequate awareness of reverse supply chain and environmental issues (Shamsuddoha 2011). Thousands of poultry farms have grown up through private ownership without getting adequate scientific knowledge on it. A number of poultry owners practice the triple bottom line framework of sustainability (social, economic and environment) in unorganized way (Shamsuddoha, 2010). This industry does significantly contribute to society in terms of economic, employment generation, and protein supply and poultry owners are currently beginning to integrate foreign technology and breed in their commercial farms and this has the potential of making the industry more profitable and sustainable. There are still huge opportunities to utilize poultry wastages as not many farmers are capitalizing on waste management practices. Poultry rearing along with reverse supply chain and $3 \mathrm{R}$ concepts can play a significant role in keeping the environment intact, generating more income by making by-products from poultry wastage, eliminating poverty, empowering rural women, fulfilling nutritional needs, providing food and protein security. 


\section{A SIMULATION SUPPLY CHAIN MODEL FOR POULTRY INDUSTRY}

Reverse supply chain have been appreciated and implemented by number of world's largest companies like Wal-Mart and Nokia. Wal-Mart processing centres are utilising reverse logistic aspects of repairs, replacement part return to customers, inspection, salvage, disposal and reworking such as upgrades (Krumwiedea and Sheub, 2002). Companies are now applying reverse supply chain and 3R concepts for the sake of ensuring sustainability, environment restoration, customer satisfaction, and government policy etc. and these practices are not always non-profit oriented. This research examines the reverse supply chain within the existing poultry process based on simulation modelling. The in-depth interviews with farm executives clearly identified a lack of usage of existing poultry wastes. This lack of poultry waste management practices has contributed towards environment pollution as the waste is currently dumped onto vacant land and rivers.

Table 1: Quantity of Poultry wastes (Monthly)

\begin{tabular}{|l|c|l|l|}
\hline Name of Waste & Waste Unit/Month & By-Products & Usage \\
\hline \multirow{2}{*}{ Poultry litter } & 324,000 & Fertilizers & Crop industry \\
\cline { 3 - 4 } & $\mathrm{Kg}$ & Bio-gas & Industry/home user \\
Charcoal & \\
intestines and feed & Feed-3600 Kg & Fish feed & Fish industry \\
\hline Rejected eggs & 29,000 & Biscuits & Bakery industry \\
(unbroken) & & and cakes & \\
\hline Rejected eggs (broken) & 20,000 & Fish feed & Fish industry \\
\hline Processed feathers & $500 \mathrm{~kg}$ & Beds and pillows & Bed and pillow \\
& & & industry \\
\hline Chicken paste from & 500 & Fish and & Fish and poultry \\
dead and culled birds & & duck feed & industry \\
\hline
\end{tabular}

Source: In-depth Interview 
The participant farm in this case study already adopts some environmental practices that helps it to remain free from diseases and allows it to achieve economic and environmental benefits through creating valuable by-products from wastes (Shamsuddoha, 2011). Table one show the different poultry wastes including litter, feed waste, feathers, broken and rejected eggs and intestines and how these can be used as by-products. For example poultry litter may be used for making fertilizer, bio gas, charcoal and fish feed; feathers can be used as raw materials for the bed industry; reject eggs can be used for the bakery industry; and broken eggs and intestines can be used for fish feed (Shamsuddoha, 2011). Table 1 also shows the quantity of poultry wastes collected from case industry in every month.

\section{Figure 1: Environment Friendly Simulation Supply Chain Model}

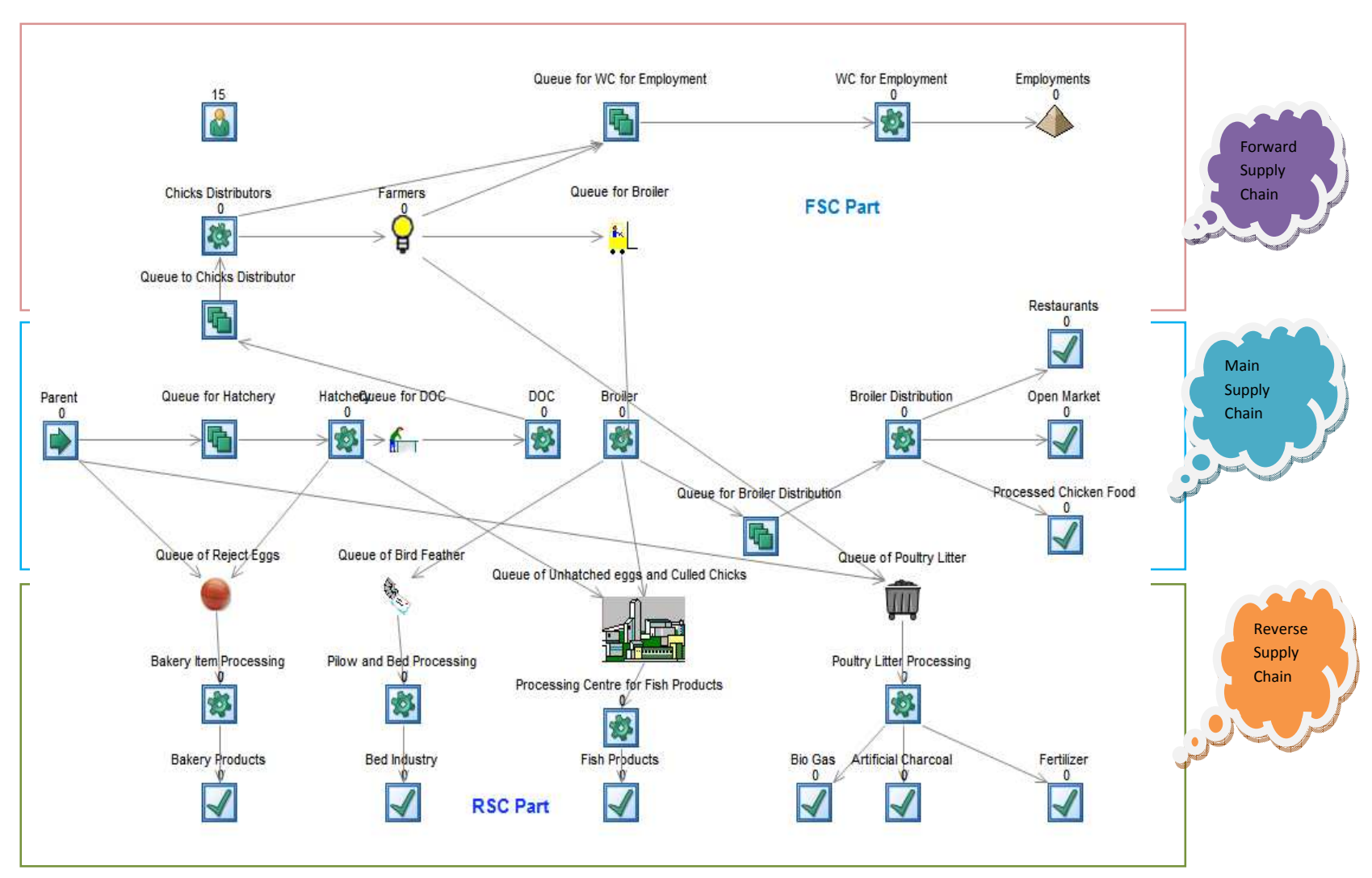

Figure one exhibits a conceptual sustainable environment friendly poultry model, using Simul8 - a simulation-modelling package. The model contains three different phases of mainstream, forward, and 
reverse supply chain. The Mainstream component includes the general supply chain of the poultry industry that starts from parent (mother of chicks) and ends up with the finished product of meat and eggs. The forward supply chain component of this simulation model consists of distributors, farmers, and intermediaries of processed and mature birds. This is the potential area of generating employment and achieving other socio-economic benefits based on volume of bird transacted or reared. The reverse supply chain phase consists of managing poultry wastes of broken and un-hatched eggs, poultry litter and poultry feather etc -these being the main focal point of this research.

Table 2: KPI's of different objects of poultry model

\begin{tabular}{|c|c|c|c|c|c|c|}
\hline $\begin{array}{l}\text { Simulation } \\
\text { Object }\end{array}$ & $\begin{array}{l}\text { Performance } \\
\text { Measure } \\
\end{array}$ & Run 1 & Run 3 & Run 5 & Av. & $95 \%$ \\
\hline \multirow{4}{*}{$\begin{array}{l}\text { Broiler } \\
\text { Distribution }\end{array}$} & Waiting \% & 0.00559 & 0.0041 & 0.00488 & 0.00476 & 0.0056 \\
\hline & Working $\%$ & 99.9944 & 99.9959 & 99.9951 & 99.9952 & 99.9960 \\
\hline & Completed Jobs & 139918 & 140104 & 139966 & 139969.4 & 140091.9 \\
\hline & Average use & 0.28571 & 0.28571 & 0.28571 & 0.28571 & 0.28571 \\
\hline \multirow{3}{*}{$\begin{array}{l}\text { Chicks } \\
\text { Distributors }\end{array}$} & Waiting \% & 12.6852 & 12.8124 & 12.9402 & 12.8533 & 12.9934 \\
\hline & Working \% & 78.4507 & 78.3692 & 78.2827 & 78.3383 & 78.4301 \\
\hline & Completed Jobs & 109812 & 109782 & 109576 & 109722 & 109849.2 \\
\hline \multirow{2}{*}{ Broiler Queue } & Av. queue size & 0 & 0.28571 & 0 & 0.11429 & 0.30857 \\
\hline & Items Entered & 108448 & 108405 & 108241 & 108352.8 & 108461.3 \\
\hline \multirow{3}{*}{$\begin{array}{l}\text { Queue for Broiler } \\
\text { Distribution }\end{array}$} & Av. queue size & 80081.7 & 79768.2 & 79489.1 & 79764.1 & 80054.05 \\
\hline & St Dev of Q. Time & 1.49016 & 1.48921 & 1.4865 & 1.48717 & 1.49018 \\
\hline & Items Entered & 531386 & 531241 & 530276 & 530898 & 531471.9 \\
\hline $\begin{array}{l}\text { Employment } \\
\text { Queue }\end{array}$ & Items Entered & 273 & 263 & 302 & 284.2 & 304.3981 \\
\hline $\begin{array}{l}\text { Queue of Bird } \\
\text { Feather }\end{array}$ & Av. Queue Time & 5385 & 5407 & 5468 & 5454.8 & 5536.654 \\
\hline $\begin{array}{l}\text { Queue of Poultry } \\
\text { Litter }\end{array}$ & Items Entered & 2504 & 2522 & 2465 & 2489 & 2518.3 \\
\hline $\begin{array}{l}\text { Queue of Reject } \\
\text { Eggs }\end{array}$ & Items Entered & 8161 & 8324 & 8365 & 8303.4 & 8431.652 \\
\hline $\begin{array}{l}\text { Queue of Un- } \\
\text { hatched/Culled } \\
\text { Chicks }\end{array}$ & Items Entered & 26106 & 25924 & 26066 & 26030.4 & 26154.46 \\
\hline Restaurants & Completed Job & 28120 & 28083 & 28066 & 28028 & 28136.15 \\
\hline Parent & Number Entered & 140030 & 140070 & 139999 & 140058.2 & 140122.8 \\
\hline \multirow{2}{*}{ Hatchery } & Completed Jobs & 137317 & 137262 & 137148 & 137269.4 & 137358.3 \\
\hline & Average use & 0.28571 & 0.28571 & 0.28571 & 0.22857 & 0.3872 \\
\hline
\end{tabular}


The model developed allows the researcher to demonstrate and understand how poultry wastes provide the input (raw materials) to other by-product processing plant in the same industry. The simulation model has the capability to assess the volume of wastes that can use as the input of by-products. Industrialist will be able to simulate the different distributions in various work centres like parents, hatchery, broiler, and other processing centres to gain a better understanding of potential outcomes and to gain insight with respect to potential opportunities. The model is also able to use real life data through MS Excel input and allow the researcher to run the model based on historic data from the case in question. The model can be easily customized as per the needs of individual farms requirement. Poultry owners can run the simulation model for various scenarios to see what changes will come based on their real data.

\section{MODEL IN REAL LIFE ENVIRONMENT}

The researchers collected historic data from the case farm, which provided parameters for the model and used as artifact in the Simul8 software. These artifacts were design as work entry, queue, work centre and work and work exit. For example, parent is a work centre in this simulation model and it generates around 140000 chicks per week. To gain the real knowledge on distribution pattern of this work centre, researchers used existing database relating to production charts, time, and volume. This was how each artifact in this model was designed to represent the "real" world. The model runs for a week having 10 hours working duration a day. Parent work centre is producing on an average of 140,000 hatcheable eggs that directly goes to the queue for the hatchery work centre. The process and parameters for the model includes 80 hatchery machines to hatch these eggs, twenty-one days needed to hatch the eggs that produced broiler chicks called day old chicks (DOC). The DOC then goes to distributors for distribution to the different regions. After 25-35 days, the DOC becomes mature chickens and are ready to be supplied to the open market, restaurants, and processing centres. The rejected eggs, feathers, culled birds, and litter are generated after a certain interval. All these aspects are represented in individual supply chains to 
produce different by-products. There are also different technology and methods used to recycle, reuse, and reduce the poultry wastes.

Table 2 contains KPI's of different objects of the simulation model including various work centre, storage, and work exit. There are many ways to compare, contrast, and display the results of the simulation, for example, using graphs, pie charts, random runs, trial runs etc. In this study, the model ran through five different trials and Table 2 represents the results of one, three, and five trials together with the average. Trial runs provide different results with minor variations, which are vital for decision-making and allows the decision maker to apply effective strategies to save time, money, and energy. Numerous experiments and analyses can be carried out in the model environment by providing various inputs to find out optimum output. The model is also able to assess volume of employment, wastage, by-products. For example, in Table 2, various results of waiting-working percentages and completed jobs for broiler work centre are shown in the table it shows that $99.99 \%$ items were working which is good for queue management of broiler. The model also shows that in the chicks distributor work centre, item working was about $78.45 \%$, waiting item around 12.68 and the rest of the items were lost in the process. This means that we can tune the work centre here by adjusting different figures to see how we can achieve better working percentages and a smooth supply chain for throughput. The model also has a feature to calculate carbon emission from total power consumption if required.

\section{CONCLUDING REMARKS}

In this paper, the authors developed a proposed simulation model for the poultry industry by incorporating mainstream, forward, and reverse supply chains. This model will help entrepreneurs to gain insights and a better understanding of reverse supply chain network problems of waste management and recycling. The model is comprehensive and consists of wastes, production, distributors, various process 
centre, different outputs and realistic process centres like diverse process and storage unit. The proposed model can be applied to address a variety of recycling issues associated with reverse supply chain and environment and shows how the poultry industry can make various by-products from its wastage instead of the waste throwing to the rivers and vacant lands. . The model demonstrates that wastage can contribute towards the establishment of many small industries with the potential of creating more employments and income. The model can also be further extended, modified, or tuned in several directions (i.e. Forward and reverse chains) to allow entrepreneurs to evaluate waste implications. For example, in practice, the main operation and recycling matters are hampered by situations like heavy rainfall, flood, natural calamity similar to cyclones, droughts, poultry disease (bird-flu), alternative meat price, and cultural influences etc. In these scenarios, the parameter values (e.g. percentage of workflow) can be change as per situation and the implication analysed. Potential future research could focus on testing the entire process model and artifacts to understand the total industry operations and its optimality which could provide valuable insights to help Bangladeshi poultry stakeholders to operate their business in a more sustainable and environment friendly way.

\section{REFERENCES}

Canan, K., Carol, P. \& Robert, D. K. 2007. Linking forward and reverse supply chain investments: The role of business uncertainty. Journal of Operations Management 25, 1141-1160.

Corbett, C. J. \& Kleindorfer, P. R. 2003. Environmental management and operations management: introduction to the third special issue. Production and Operations Management, 12, 287-289.

Cox, J. F., Blackstone, J. H. \& Spencer, M. S. 1995. APICS Dictionary (8th ed.). Falls Church, VA.: American Production and Inventory Control Society.

Elkington, J. 2004. Enter the triple bottom line in Henriques, A. and Richardson, J. (Eds); The Triple Bottom Line: Does It All Add up? Earthscan, 1-16.

Guide, J. V. D. R. \& Van, L. N. W. 2002. The reverse supply chain. Harvard Business Review, 80, 25-26. 
Gungor, A. \& Gupta, S. M. 1999. Issues in environmentally conscious manufacturing and product recovery: a survey. Computers and Industrial Engineering, 36, 811-853.

Jennings, P. D. 1995. Ecologically sustainable organizations: an institutional approach. The Academy of Management review, 20, 1015-1052.

Jonathan, L. D., Klassen, R. \& Jayaraman, V. 2007. Sustainable supply chains: An introduction. Journal of Operations Management, 25, 1075-1082.

Klassen, R. D. \& Vachon, S. 2003. Collaboration and evaluation in the supply chain: the impact on plantlevel environmental investment. Production \& Operations Management, 12, 336-352.

Kocabasoglu, C., Prahinski, C. \& Klassen, R. D. 2007. Linking forward and reverse supply chain investments: the role of business uncertainty. Journal of Operations Management, 25, 1141-1160.

Krumwiedea, W. D. \& Sheub, C. 2002. A model for reverse logistics entry by third-party providers. Omega, 30.

Lummus, R. R. \& Vokurka, R. J. 1999. Defining supply chain management: a historical perspective and practical guidelines. Industrial Management \& Data Systems, 99, 11-17.

Nielsen, H. 2007. Socio-Economic Impact of the Smallholder Livestock Development Project in Bangladesh: Results of the Second Impact Survey. Stamholmen, Denmark: DARUDEC.

Pelletier, N. 2008. "Environmental performance in the US broiler poultry sector: Life cycle energy use and greenhouse gas, ozone depleting, Acidifying and eutrophying emissions." Agricultural systems 98:67-73.

Prahinski, C. \& Kocabasoglu, C. 2006. Empirical research opportunities in reverse supply chains. Omega: The International Journal of Management Science, 34, 519-532.

Quinn, F. J. 1997. “What's the buzz?”. Logistics Management, 36, 43-7.

Reneta 2005. Reneta Statistical Yearbook of Bangladesh.

Shamsuddoha, M. 2010. A sustainable supply chain process model for Bangladeshi poultry industry. Doctoral Students Colloquium 2010. Perth, Australia: Curtin Business School. 
Shamsuddoha, M. 2011. Applying reverse supply chain in the poultry industry. In: Jefferson, T., Shamsuddoha, M. \& Young, E. (eds.) Emerging Research Initiatives and Developments in Business: CGSB Research Forum 2011. Perth, Australia: Curtin University.

Shamsuddoha, Mohammad. 2011. "Reverse supply chain process as environmental sustainability in the poultry industry of Bangladesh." In Doctoral Colloquium 2011, ed. Jenny Goodison. Perth: Curtin Business School, Curtin University.

Shamsuddoha, M. \& Sohel, M. H. 2004. Problems and prospects of poultry industry of Bangladesh: a study on some selected areas. The Chittagong University Journal of Business Administration, 19, 273-286.

Shamsuddoha, M. \& Sohel, M. H. 2008. Poultry rearing - an alternative income generating activity for rural women development of Bangladesh. The Chittagong University Journal of Business Administration, Bangladesh, 20, 119-132.

Shrivastava 1995a. The role of corporations in achieving ecological sustainability Academy of Management Review, 20, 936-60.

Srinivas, H. 2007. The $3 R$ Concept and Waste Minimization [Online]. Available: http://www.gdrc.org/uem/waste/3r-minimization.html [Accessed 10/02/2011 2011].

Steinfeld, Henning, Pierre Gerber, T. D. Wassenaar, Vincent Castel, Mauricio Rosales and Cees de Haan. 2006. "Livestock's long shadow: environmental Issues and options." In Livestock, Environment and Development Initiative. Rome: United Nations Food and Agriculture Organization.

Yin, R K. 1994. Case study research: Design and methods. Newbury Park, CA: Sage. 